\title{
Effect of amitraz treatments on honey bees and on the honey bee tracheal mite
}

\author{
JD Vandenberg *,**, H Shimanuki \\ USDA-ARS Beneficial Insects Laboratory, Beltsville, MD, 20705
}

(Received 13 September 1989; accepted 14 March 1990)

\begin{abstract}
Summary - Two formulations of the acaricide amitraz were tested for their effect on the honey bee tracheal mite, Acarapis woodi. An aerosol formulation of the acaricide was applied at 25 and $50 \mathrm{mg}$ per colony. In 1 experiment, no difference in infestation rate was detected among treated and control colonies throughout the $8 \mathrm{wk}$ of the experiment. In a 2 nd experiment there was a significant decline in the infestation rate among treated colonies. Further testing of this formulation is warranted. An amitraz formulation in slow-release plastic strips was tested on infested worker bees in small mailing cages. Doses higher than ca $0.01 \mathrm{~g}$ amitraz/cage caused significant bee mortality. However, even at high doses $(0.05$ and $0.1 \mathrm{~g}$ amitraz/cage) living mites were observed after $4 \mathrm{~d}$ of continuous exposure to amitraz. This formulation is not suitable for treating bees within mailing cages.
\end{abstract}

Acarapis woodi / Amitraz / Apis mellifera / acarine disease / chemical control

\section{INTRODUCTION}

Following the introduction of the honey bee tracheal mite, Acarapis woodi (Rennie), into the USA in 1984 (DelfinadoBaker, 1984), beekeepers in many states have attributed much overwintering colony mortality to the mite. Restrictions on the interstate shipment of colonies and caged bees have caused further problems for beekeepers. A review of this mite in North America has been provided by Kjer et al (1989). Studies of mite control were con- ducted by several research groups (Kjer et al, 1989), with mixed results.

Amitraz is an acaricide which has been registered for the control of certain livestock pests. Topical applications to adult worker and queen bees have shown to be useful in preventing tracheal mite infestation (Eischen et al, 1986) and in killing adult mites (and some of the juveniles) in infested workers (Eischen et al, 1987). Moffett et al (1988) tested 4 formulations of amitraz in infested colonies and achieved some degree of control with all 4.

\footnotetext{
* Correspondence and reprints

** Present address: USDA-ARS, Utah State University, Bee Biology \& Systematics Laboratory, Logan, UT, 84322-5310, USA
} 
Our objective was to determine the effectiveness of an aerosol formulation of amitraz in controlling mite infestation in honey bee colonies. We also determined the efficacy for mites of amitraz formulated in slow-release plastic strips using infested bees in small mailing cages. Finally, we monitored bee mortality in small mailing cages during amitraz treatments.

\section{MATERIALS AND METHODS}

We tested 2 formulations of amitraz ( $N, N$-di(2,4-xylyliminomethyl)-methylamine) obtained from Nor-Am Chemical Co (Wilmington, DE, USA). One was a $\mathrm{CO}_{2}$-propelled aerosol and the other was a slow release plastic strip ("cattle bands", $10 \%$ active ingredient).

The aerosol was tested in mite-infested colonies in Pennsylvania in 1986 and 1987. Three treatments (25 and $50 \mathrm{mg}$ per colony, and untreated controls) were applied to 7 replicate colonies each. The aerosol was applied by inserting the spray wand into the colony entrance and directing the spray upward. Each colony was sampled immediately prior to treatment, and at 4,6 and 8 wk after treatment. Each sample consisted of 100 bees collected in $70 \%$ ethanol. Infestation rates were determined by the $\mathrm{KOH}$ method described by Delfinado-Baker (1984). Each bee was scored for the presence or absence of mites and the percentage of bees infested in each sample was calculated. Percentage data were subjected to angular transformation. Transformed data from each experiment were subjected to repeated-measures analysis of variance to detect time or treatment effects.

The slow-release plastic strips were tested in wooden queen mailing cages (Herbert et al, 1988). For each experiment, 5 or 10 replicate cages (each containing 8-12 adult worker bees) were established using bees collected from a colony in which approximately $50 \%$ of the bees were infested. Bees were given powdered sugar candy and water ad libitum. They were maintained at room temperature (ca $25^{\circ} \mathrm{C}$ ) on a laboratory bench with normal room air circulation and monitored daily for 4-6 d for survival. For our purposes, a $1 \mathrm{X}$ treatment was a piece of strip $(0.5 \times 0.5 \mathrm{~cm})$ weighing $0.055 \mathrm{~g}$. Higher amitraz doses were administered by inserting multiple pieces of the plastic strips into the cages.

In a separate experiment of similar design, adults were removed from cages after 4 or $6 \mathrm{~d}$ of exposure. Tracheae from each bee were removed and immediately examined for the presence of living or dead mites according to the method of Eischen et al (1987).

\section{RESULTS AND DISCUSSION}

Pre-treatment infestation levels for bees sampled from the 21 colonies used in the 1986 experiment ranged from 53 to $98 \%$. Analysis of variance revealed no significant difference among the treatments $(P=$ $0.51)$ during the course of the experiment. Among all treatments there was a significant decline in infestation between the beginning and end of the experiment $(P=$ 0.007 ). There was no significant interaction between time and treatment.

In 1987, pre-treatment infestation rates were much lower (range 2-12\%). Analysis of variance showed a significant interaction between time and treatment $(P=0.02)$. In particular, the difference among treatments between the pre-treatment sample and the final sample (8 wk later) was significant $(P=0.008)$. The average infestation rate among untreated colonies increased from 4.1 to $7.3 \%$. Among colonies treated with $25 \mathrm{mg}$, the infestation decreased from 3.1 to $1.4 \%$, and among colonies treated with $50 \mathrm{mg}$ it decreased from 5.5 to $1.7 \%$.

The failure to detect significant treatment effects in the 1st experiment may have resulted from conducting the test between October and December in northern Pennsylvania, when there was little turnover in the adult population. Furthermore, our sampling scheme only assessed the presence or absence of mites, not their vitality. In the test conducted by Moffett et al 
(1988), although infestation rates in both treated and control colonies were similar, the number of live mites present in bees in aerosol-treated colonies was reduced by $93 \%$ within 3 wk. The 2nd experiment was conducted between June and August. Normal turnover of adults may have rid the treated colonies of infested bees and allowed the effect of the treatments to be detected by our sampling scheme (ie the treatment killed the mites, the infested bees died, and new bees were uninfested).

In tests of amitraz strips in queen cages, most doses tested resulted in a significant increase in bee mortality compared with controls (table I). Only the $1 \mathrm{X}$ and $2 \mathrm{X}$

Table I. Adult worker honey bee mortality within mailing cages following treatment with amitraz.

a $1 X=(0.5 \times 0.5) \mathrm{cm}$ plastic strip $(0.055 \mathrm{~g})$ with $10 \%$ amitraz. ${ }^{b}$ Average percent mortality after 4 d. Experiment 1 with 10 replicate cages (8-12 adult worker bees per cage). Experiments 2-5 with 5 replicate cages (8-12 bees/cage). Means within each experiment followed by the same letter not significantly different by analysis of variance (Student-Newman-Kuels, $P<0.05$ ). c Plastic strip without amitraz.

\section{Experiment Treatment a $\%$ Bee Mortality b}

\begin{tabular}{ccr}
\hline & & \\
& Untreated & $23 \mathrm{a}$ \\
& $10 \mathrm{X}$ & $88 \mathrm{~b}$ \\
& $20 \mathrm{X}$ & $81 \mathrm{~b}$ \\
& Untreated & $9 \mathrm{a}$ \\
& $1 \mathrm{X}$ & $3 \mathrm{a}$ \\
3 & $2 \mathrm{X}$ & $15 \mathrm{a}$ \\
& Untreated & $8 \mathrm{a}$ \\
& $2 \mathrm{X}$ & $25 \mathrm{~b}$ \\
4 & $4 \mathrm{X}$ & $53 \mathrm{c}$ \\
& Untreated & $30 \mathrm{a}$ \\
& $4 \mathrm{X}$ & $85 \mathrm{~b}$ \\
5 & $6 \mathrm{X}$ & $86 \mathrm{~b}$ \\
& Untreated & $17 \mathrm{a}$ \\
& $10 X$, no amitraz & $13 \mathrm{a}$ \\
& $10 \mathrm{X}$ & $89 \mathrm{~b}$ \\
& &
\end{tabular}

treatments in experiment 2 resulted in mortality which did not differ from untreated controls. A plastic strip without amitraz (10X-size) had no significant effect on bee mortality (table I, experiment 5). Bee mortality due to amitraz treatment has been shown previously. Herbert et al (1988) obtained $28 \%$ mortality within $48 \mathrm{~h}$ after treating workers in mailing cages (identical to ours) with a smoking amitraz strip. Control mortality in their test was $0 \%$. Eischen et al (1987) reported $10-100 \%$ bee mortality when amitraz was applied twice topically to workers. Single topical applications of amitraz also resulted in bee mortality at the highest dose tested.

Even high doses of amitraz in strips failed to kill all mites after $\mathbf{4}$ or $\mathbf{6 d}$ (table II). The $2 X$ treatment is the only one shown in table II which might not cause significant bee mortality within $4 \mathrm{~d}$ (cf table I). Howev$e r$, at this dose, most infested bees still had living mites within their tracheae after $6 \mathrm{~d}$. Thus, at amitraz doses low enough to prevent bee mortality, there was no evidence of mite mortality. We did not test the distribution of amitraz on bees or within cages following treatment. However, bees moved about normally within the cages and unavoidably came in direct and frequent contact with the plastic strips.

\section{CONCLUSION}

The aerosol formulation of amitraz may aid in tracheal mite control within infested colonies but needs to be tested further under a variety of conditions at various infestation rates. Amitraz in slow-release plastic strips, as presently formulated, is not suitable for tracheal mite control in queen mailing cages. 
Table II. Living and dead mites present within tracheae of adult worker honey bees treated in mailing cages with amitraz in plastic strips.

a $1 \mathrm{X}=0.5 \times 0.5 \mathrm{~cm}$ plastic strip $(0.055 \mathrm{~g})$ with $10 \%$ amitraz. ${ }^{b}$ Number of adult bees containing some live mites (Live), all dead mites (Dead), or no mites (None).

\begin{tabular}{cccccc}
\hline Treatment a & Exposure time & $\begin{array}{c}\text { No bees } \\
\text { examined }\end{array}$ & Live & $\begin{array}{c}\text { No }{ }^{\circ} \\
\text { Dead }\end{array}$ & None \\
\hline Untreated & $6 \mathrm{~d}$ & 39 & 21 & 0 & 18 \\
$2 \mathrm{X}$ & 6 & 29 & 11 & 5 & 13 \\
$4 \mathrm{X}$ & 6 & 20 & 5 & 8 & 7 \\
Untreated & $4 \mathrm{~d}$ & 46 & 20 & 1 & 25 \\
$10 \mathrm{X}$ & 4 & 2 & 2 & 0 & 0 \\
$20 \mathrm{X}$ & 4 & 3 & 1 & 0 & 2 \\
\hline
\end{tabular}

\section{ACKNOWLEDGMENTS}

We thank EW Herbert, Jr, for suggestions and $J$ Hogan, $F$ Leonard and $M$ Ormes for technical assistance. A Hack and V Toblan (Nor-Am Chemical Co) supplied the amitraz. J Steinhauer (Pennsylvania Department of Agriculture) was most helpful in finding bees and processing samples. Partial funding was provided through the IR-4 Minor Use Pesticide Program (Rutgers University). Helpful reviews of a draft of this paper were provided by $E$ Evans and V Tepedino. Partial support during the analysis and manuscript preparation phases of this work was provided by the Utah Agricultural Experiment Station, Journal Paper No 3909. Mention of a trademark, proprietary product, or vendor does not constitute a guarantee or warranty by the USDA, nor does it imply approval to the exclusion of other products or vendors.

Résumé - Effets de traitements à l'amitraze sur les abeilles et sur Acarapis woodi. Nous avons testé l'action de 2 formulations de l'acaricide amitraze sur l'acarien des trachées, Acarapis woodi. Une formulation aérosol a été appliquée aux doses de 25 et $50 \mathrm{mg}$ par colonie. Dans la $1^{\text {re }}$ expérience, qui a duré 8 semaines, aucune différence n'a été trouvée dans le taux d'infestation des colonies traitées et des témoins. Dans la seconde expérience, une baisse significative du taux d'infestation a été notée chez les colonies traitées. L'absence d'effet significatif lors de la $1^{\mathrm{re}}$ expérience peut être due à la période de traitement (automne) ou au mode d'échantillonnage. Nous n'avons pas vérifié si les acariens à l'intérieur des abeilles étaient vivants ou morts. II est nécessaire de tester davantage cette formulation.

Une formulation d'amitraze en bandelettes plastique à effet retard a été testée sur des ouvrières infestées, placées en cagettes d'expédition. Les doses supérieures à environ $0,01 \mathrm{~g}$ d'amitraze/cagette ont provoqué une mortalité significative chez les abeilles (tableau I). Pourtant, même après application continue pendant $4 \mathrm{j}$ de fortes doses $(0,05$ et $0,1 \mathrm{~g}$ d'amitraze/ cagette), des acariens ont été retrouvés vivants (tableau II). Cette formulation n'est pas adaptée au traitement des abeilles en cagettes d'expédition.

Apis mellifica / Acarapis woodi / acariose / lutte chimique / amitraze 
Zusammenfassung - Die Wirkung von Amitraz-Behandlungen auf Honigbienen und Tracheenmilben. Zwei Formulierungen des Akarizids Amitraz wurden hinsichtlich ihrer Wirkung auf die Tracheenmilbe der Honigbiene, Acarapis woodi, geprüft. Eine Aerosol-Formulierung wurde in Dosen von 25 und 50 mg je Volk angewandt. In dem ersten Experiment wurde in den 8 Wochen des Versuchs kein Unterschied in der Befallsrate zwischen behandelten und Kontrollvölkern gefunden. Der Mißerfolg bei diesem ersten Versuch mag an der Jahreszeit (Herbst) liegen oder an dem Schema der Probenentnahme. Ob die Milben in den Tracheen lebend oder tot waren wurde nicht untersucht. Weitere Versuche sind notwendig. Ferner wurden befallene Arbeitsbienen in Versandkäfigen mit einer Amitraz-Formulierung in KunststoffStreifen mit langsamer Abgabe behandelt. Höhere Dosen als etwa 0,01 g Amitraz per Käfig verursachten eine beträchtliche Bienenmortalität (Tabelle I). Aber sogar bei hoher Dosierung $(0,05$ und $0,1 \mathrm{~g}$ Amitraz/ Käfig) wurden nach vier Tagen ständiger Einwirkung von Amitraz noch lebende Milben festgesteilt (Tabelle II). Diese Formulierung ist also zur Behandlung von Bienen in Versandkäfigen nicht geeignet.
Apis mellifera / Acarapis woodi / Milbenkrankheit / chemische Bekämpfung / Amitraz

\section{REFERENCES}

Delfinado-Baker M (1984) Acarapis woodi in the United States. Am Bee J 124, 805-806

Eischen FA, Pettis JS, Dietz A (1986) Prevention of Acarapis woodi infestation in queen honey bees with amitraz. Am Bee $J 126$, 498-500

Eischen FA, Pettis JS, Dietz A (1987) A rapid method of evaluating compounds for the control of Acarapis woodi (Rennie). Am Bee $J$ 127, 99-101

Herbert EW Jr, Witherell PC, Shimanuki H (1988) Control of Varroa jacobsoni on honey bees in queen cages and small laboratory cages using amitraz fluvalinate and Apitol ${ }^{\top \mathrm{M}}$. Am Bee J 128, 289-292

Kjer KM, Ragsdale DW, Furgala B (1989) A retrospective and prospective overview of the honey bee tracheal mite, Acarapis woodi R. Part II. Am Bee J 129, 112-115

Moffett JO, Wilson WT, Cox RL, Ellis M (1988) Four formulations of amitraz reduced tracheal mite, Acarapis woodi, populations in honey bees. Am bee $J$ (Abstract) 128, 805806 